\title{
A Membership Categorization Analysis of the Waco Siege: Perpetrator-Victim Identity as a Moral Discrepancy Device for 'Doing' Subversion
}

\author{
by Jonathan Clifton \\ Université Charles-de-Gaulle
}

\author{
Sociological Research Online 14(5)8 \\ <http://www. socresonline.org.uk/14/5/8.html> \\ doi:10.5153/sro.2002
}

Received: 28 Apr 2009 Accepted: 19 Nov 2009 Published: 30 Nov 2009

\begin{abstract}
This paper seeks to build on previous work on the doing of politics as a members' practice. More specifically, it seeks to add to the growing work on perpetrator-victim identities by explicating how perpetrator identity is projected from individuals to the morally self-organized group 'the government', and so, in this way, subversion is achieved. Using membership categorization analysis (MCA) as a research methodology and data of naturally-occurring talk-in-interaction taken from recordings of the negotiations between the FBI and David Koresh during the Waco siege, this paper explicates how Koresh invokes perpetrator-victim identities to 'do' subversion. Findings indicate that this is achieved through his selfavowal of victim identity and consequent ascription of perpetrator identity to the FBI agents. Through this category work, Koresh is able to set up a moral discrepancy between the de jure rights and responsibilities of law enforcement officers and de facto actions of the FBI agents. This identity work is then transferred to the government which becomes an integral, rather than incidental, part of the interaction. In this way, Koresh does subversion and is able to turn the world upside down by proposing a revolutionary theocratic, rather than democratic, moral order.
\end{abstract}

\section{Keywords: Membership Categorization Analysis, Identity, Moral Discrepancy, Victim-Perpetrator, Subversion}

\section{Introduction}

1.1 Membership categorization analysis (MCA), developed by Harvey Sacks' (1972a, 1972b, 1979, 1992) in the 1960s and early 1970s, analyses the way in which people and places are categorized by members in order to make sense of the social world. In one of his seminal articles on categorization, Sacks (1979) analyses the way in which categories can be used to challenge the existing social order. Yet, despite this early observation, little work has been carried out into the way into which members categorize in order to 'do' politics as a locally accomplished and occasioned matter (though see, for example, Mazeland 2003, Housley 2002, Housley and Fitzgerald 2001, 2003, and 2009, Leudar et al. 2004, and Eglin and Hester 1999 and 2003). Situated within a cumulative paradigm of social research, this paper seeks to add to previous research which uses MCA to explicate members' procedures and methods through which the relationship between the government and the governed is locally accomplished. More specifically, by building on Housley's (2002) and Housley and Fitzgerald's (2003and 2009) work on moral discrepancies, this paper examines how the mobilization of moral discrepancies, related to the victim-perpetrator standard relational pair (SRP), is used to 'do' subversion. The paper is divided into four parts. First, MCA as a research methodology is discussed. Second, background information on the Waco siege is provided. Third, two sequences of talk-in-interaction, taken from audio-recordings of a telephone conversation between Koresh and the FBI are analyzed. The paper closes with conclusion and observations.

\section{Method}

\section{Membership categorization analysis}

2.1 Harvey Sacks (1972a, 1972b, 1992) developed MCA in order to explicate the way in which members use categorization as resources to make sense of everyday life. In perhaps his most famous article on categorization, the so-called 'the baby cried, the mommy picked it up' article (Sacks 1972a), Sacks asked the question: why is it that we hear that it is the mommy of the baby who picked it up? He proposed that 
categorization is essential to understand the utterance and he sought to make visible the apparatus that allows an understanding of 'what is going on'. The apparatus that he proposed consists of membership categorization devices, such as family, which contain categories (i.e., classifications that could be used to describe people) that 'go together' such as mommy and baby. Sacks then specified rules of application that explicate how the apparatus works and which allow us as members (or as analysts) to understand that it is the mother of the baby who picks it up. In short, it is the fact that the mother and baby come from the same devices ('family' and 'stage of life') that allows members to link the categories together and so understand the utterance as being the mother of the baby who picked it up. Moreover, in the same article Sacks developed the notion of category-boundness (i.e., certain activities are bound to certain categories such as crying is bound to the identity baby). Therefore, in the instance 'the baby cried' we know it is a baby from the stage of life device since crying is normally associated with babies and not adults. Furthermore, Sacks (1972b) pointed out that categories often exist in standard relational pairs (e.g. husband-wife, parent-child, victim-perpetrator) and that such relational pairs constitute a locus for a set of rights and obligations which act as constraints and resources for allowable contributions to interaction. Members design their talk and actions according to the recipient's in situ identity and so orient to the accountable nature of allowable contributions. Thus, in the example Sacks (1972a) gives, a mother has a moral obligation and right to pick up her crying infant. Consequently, when a member is ascribed, or claims, membership of a particular category this also gives him or her access to certain socially approved resources (such as picking up a child). The use, or non-use, of these resources is a morally accountable matter (cf. Garfinkel 1967) and through using categorization to orient to the moral accountability of interaction, members orient to a presupposed (yet reified) social/moral order which is in fact reflexively reproduced in the course of the activity.

2.2 Since Sacks' death in 1975, MCA has been refined and developed by numerous researchers. Significantly, researchers have criticized Sacks' notion of categorization for being too ambiguous as to the indexical and situated nature of categories. For example, Hester (1994: 223) and Hester and Eglin (1997a) claim that whilst Sacks was obviously aware of the indexical nature of categorizing, his analysis of the baby cried, the mommy picked it up, can be interpreted in terms of members making use of pre-existing categories to make sense of social action. This research and others (e.g. Jayyusi 1984, and Housley and Fitzgerald 2002) has sought to clarify this ambiguity and has placed a greater emphasis on the occasioned nature of categorization, and consequently it 'eschews the analytical location of categories within specific, stable culturally defined collections' (Housley and Fitzgerald 2002: 68). This perspective, therefore, stresses the fact that categories do not reflect pre-discursive entities that are 'out there somewhere' and which members use to make sense of what is happening. Rather, what constitutes a category, and the predicates (i.e., expectable features, characteristics, behaviors, states of mind etc) that accompany categories, are locally produced and are designed to 'do' social actions. Jayyusi (1984: 37), therefore, makes the distinction between category-bound features which conventionally accompany a particular category and category-generated features which are situatedly achieved through their tie to some category. But even having added this refinement to Sacks' notion of category-boundness, it is important to note that the formulation of predicates that are considered to be 'conventionally accompanying' a category is also an in situ achievement and there is nothing a priori about the association of certain predicates with certain categories. A further refinement to Sacks' notion of MCA, which is crucial to the general thrust of this article, is that of the transpersonal projection of category features so that predicates ascribed to, or claimed by, one member can be transferred to other members of the same a morally self-organized group (Jayyusi 1984, Coulter 1996). A morally self-organized group is defined as a group which is 'specifically constituted by its members round some set of moral-practical beliefs, commitments, codes, values, interests, concerns, etc' (Jayyusi 1984: 48). Jayyusi (1984: 50) gives the Ku Klux Klan as an example of a morally self-organized group since membership of the clan is constituted through rule-bound elective membership and membership also presupposes agreement with the avowed beliefs of the clan. Predicates linked with clansmen and the clan are thus reflexively linked so that an action of an individual clansman can be made to represent the character and activities of the clan as a whole and, similarly, beliefs of the clan as an organization can be considered to be predicates of individuals who claim, or who are ascribed, clan membership. In short, individuals within the clan and the clan (as an organization) can be said to be mutually constituting. This reflexive relationship, therefore, allows for the transpersonal projection of predicates whereby actions performed under the auspices of the group can be morally ascribable to group as a whole. Similarly, this paper argues that law enforcement officers can be seen as part of the morally self-organized group 'government'. Firstly, this is because swearing-in ceremonies, passing out parades, oaths of allegiances and so on which are often part and parcel of initiation into some forms of government service both display rule-bound elective membership crucial to morally self-organizing groups and such ceremonies also presuppose agreement with the avowed beliefs of the government that they seek to uphold. Secondly, the actions of law enforcement officers can be seen as those of the government when, situatedly, their activities are formulated as being performed under the auspices of the morally selforganized group 'the government'.

\section{MCA, the social order, and politics}

2.3 As various authors (e.g., Sacks 1979, Jayyusi 1984, Coulter 1996, Hester and Eglin 1997b, and Housley and Fitzgerald 2002) have pointed out, social order is constructed in part through the practices of members doing categorization. This is because social structure is made up of categories of people who have rights and responsibilities vis-à-vis each other. The myriad of moral rights and responsibilities, which constitutes the moral order, is not external to talk in some pre-discursive fashion. Social order, realized through categorization, is invoked in an occasioned manner as a resource for carrying out everyday social actions and, through being oriented to, social order is reflexively talked into being as a social fact that constrains and allows social action. From this perspective, social order is thus inexorably a members' accomplishment and has nothing to do with the Parsonian rule following judgmental dopes of traditional social theory. As Wilson (1991: 27), from a broadly ethnomethodological perspective, argues, 'social structure consists of matters that are described and oriented to by members of society on relevant occasions as essential resources for conducting their affairs and, at the same time, reproduced as external 
and constraining social facts through that same social interaction. Thus, we must abandon any standard Durkheimian conception of social structure that takes externality and constraint for granted as methodological stipulation'. From such an ethnomethodological perspective, in which Sacks' notion of categorization is firmly rooted, there is no prediscursive social structure that is 'out there somewhere' and which constrains and allows social action. Rather, social order is a members' achievement which is realized, inter alia, through categorization. Consequently, since there is no prediscursive social order, categorizations, and the social world that is talked into being through such categorizing, are both open to resistance as well as acceptance. This observation that categorization creates, and is created by, the social world and thus can always be organized differently, is summed up by Sacks (1979: 9) when he states that, 'roughly, we could say that what the dominant categories basically own is how it is that persons perceive reality. And there's an order of revolution which is an attempt to change how it is that persons see reality'. Sacks (1979) shows that, by using their own category 'hotrodder', teenage drivers challenge the adult world's categorization of them. This, Sacks (1979) argues, is revolutionary because such a challenge could change the way in which teenage drivers are perceived. And, since the rights and responsibilities expectably associated with 'teenage driver' and 'hotrodder' are fundamentally different, such categorization work proposes an alternative perception of social order. Should 'hotrodder' ever replace 'teenage driver' as the stable and the normative categorization then a revolution could be said to have occurred. In short, then, as Sacks (1979: 13) says, the fact that teenagers orient to their own categories means that more or less fundamental attacks are being launched against a culture which is stable by reference to everybody seeing the world for what it is, without regard to whether it is pleasant or not, whether they come out on top or not, and not seeing that they can do anything about it'. For social change to take place, a change in how categories are oriented to in talk and the predicates that are morally invoked by the use of such categories would be required, and if such category work becomes a stable reference rather than the categorizing of minority self-organized groups, then it would be truly revolutionary. In this sense, categorization can be used subversively to attack a hegemonic social order and to propose a revolutionary alternative.

2.4 Eglin and Hester (1999and 2003), provide an exemplary analysis of how categorization is an essential element in attempting to subvert the existing moral order. In their analysis of media coverage of the Montreal Massacre, they point out that the gunman's categorization of his victims, 14 female engineering students at l'Ecole Polytechnique in Montreal, as being 'a bunch of feminists' simultaneously anonymizes and politicizes them. Of the many possible ways of categorizing his victims, he chooses to ascribe to them the category feminists who, according to his suicide letter, have the predicates of seeking on the one hand to keep the social advantages of being women but on the other hand to have access to areas traditionally restricted to men such as jobs in engineering. Placing the victims of the massacre in a political categorization device allows the killer to also categorize himself politically and so claim for himself the identity of an anti-feminist counter revolutionary seeking to redress injustices in Canadian society that have been implemented through the government's tacit support of feminists by legislating discriminatory benefits for women, allowing them to enter professions traditionally reserved for men, and so on. As Eglin and Hester (2003: 55) conclude, by invoking a political membership categorization device, the killer 'provides instructions for making his actions rationally accountable as political.'

2.5 More specifically, in terms of subversion, this paper draws on Housley's (2002) and Housley and Fitzgerald's (2003 and 2009) notion of moral discrepancy in political debate. Moral discrepancy can be defined as making relevant a discrepancy between two categories that are normatively tied together. For example, Housley (2002) discusses the moral discrepancy between intention and action in debate concerning the banning of fox hunting in the UK, and Housley and Fitzgerald (2003 and 2009) discuss the mobilization of a discrepancy between blame and punishment as a way of clouding political accountability in the BSE/mad cow disease debate. In the spirit of cumulative social enquiry, this paper seeks to add to the notion of moral discrepancy by analyzing the occasioned use of a moral discrepancy between what is situatedly formulated as category-bound (de jure) and category-generated (de facto) predicates of government in political debate. More specifically, this paper explicates how moral discrepancy can be used as a political truth engine to 'do' subversion by ascribing perpetrator identity to government and victim identity to the citizen and so the moral discrepancy device can become a discursive resource through which (hegemonic) 'collectives may be questioned, disbelieved or undermined' (Housley and Fitzgerald 2009: 355).

\section{Data}

\section{Background}

3.1 On 19th April 1993, the FBI launched an assault on Mount Carmel, the headquarters of a religious cult, The Branch Davidians, led by David Koresh. This assault resulted in the deaths of 76 of the occupants and put an end to an armed siege that had lasted 51 days. The Branch Davidians were a religious cult that had broken away from the Davidian Seventh Day Adventist Church, itself an offshoot of the Seventh Day Adventist church. The Branch Davidians established their own church with its headquarters just outside Waco, Texas. The buildings, which Koresh renamed Ranch Apocalypse, included an underground bunker which contained everything needed to resist a siege: a small arsenal of weapons, 8,000 rounds of ammunition, gas masks and, allegedly, grenades and weapons that had been converted to fire on fully automatic. In 1988, David Koresh had become leader of the church. Koresh's real name was Vernon Howell, but he had changed it to David Koresh to add to his religious credibility: David alludes to the biblical House of David from which it was believed that the messiah would come and Koresh is a transliteration of Cyrus who, because he conquered Babylon and released the Jews, is regarded as the only gentile to be divinely appointed King or messiah. Moreover, adding to these apocalyptical allusions, Koresh also believed that he was the Lamb of God who was divinely appointed to open the seven seals which are seen as the precursors to the apocalypse. In short, Koresh saw himself as a prophet who was fighting against Babylon and was preparing for Armageddon in which he would be the one to reveal God's truth. 
3.2 However, the activities of Koresh and his followers were not restricted to innocent bible study. Allegations of polygamy, pedophilia, and firearms offences attracted the attention of the law enforcement agencies including The US Bureau of Alcohol Tobacco and Firearms (AFT) who had placed the ranch under surveillance. Yet, despite the fact that the surveillance operation had been compromised and Koresh knew of an impending raid, on February $28^{\text {th }} 1993$, the AFT attempted to execute a warrant to search the buildings for illegal firearms. The operation turned into a fiasco and the ensuing firefight resulted in the deaths of four law enforcement officers and six Davidians. A ceasefire was brokered and this then led to a standoff that was to last for 51 days. Following the failure of the initial attempt to execute the search warrant, the FBI took control of the operations and set up two command posts. One command post controlled the tactical side of the operations and consisted of a Special Weapons and Tactics Team (SWAT) and a Hostage Rescue Team (HRT) which allegedly received military advice and support in the form of helicopters and armored vehicles. The second command post, containing the negotiators, was set up in a hanger further from the ranch. Initially, Koresh promised to leave the buildings and he allowed some children and adults to leave but later he reneged on this promise and said that he would come out, as God had instructed him, after writing a book that revealed the truth behind the seven seals. However, as the siege dragged on and negotiations seemed to make little headway, the FBI became increasingly impatient and they started using stronger tactics such as sleep deprivation, harassment by low flying helicopters and so on. On $17^{\text {th }}$ April, Janet Reno, the Attorney General, authorized the use of force to break the deadlock and on the $19^{\text {th }}$ April, armored vehicles broke down the walls of the buildings and inserted CS gas into the ranch. During this assault, a fire, which engulfed the buildings, broke out and 76 people, including 21 children, died as a result. Controversy surrounds the origin of the fire: the official report ${ }^{[1]}$ concludes that Koresh set the buildings alight whereas others claim it was started by the weapons used by the FBI. Koresh died in the inferno and the Davidians who did escape were charged with various firearms-related offences and conspiracy to murder.

\section{The recordings and transcripts}

3.3 Throughout the siege, the FBI were in constant telephone contact with Koresh and the recordings made of these calls are now in the public domain. The data used for this paper comes from the last recorded telephone call between Koresh and FBI negotiators. It was made on 18th April 1993, the day before the siege ended. In the call, Koresh talks to Henry, one of the FBI negotiators, to complain about the use of armored vehicles to destroy cars parked outside the buildings. The transcription used for the analysis provided in this paper is the author's own transcription of the recording of the call which is publically available on the web ${ }^{[2]}$. The tape has been transcribed using the Jeffersonian transcription conventions and a list of symbols used can be found in appendix one. A less detailed transcript of the complete recording of the call, made by Mark Swett, is also publically available on the web ${ }^{[3]}$.

\section{Analysis}

\section{Preliminaries: Victim and perpetrator identity, the moral order, and subversion}

4.1 This paper centers on the negotiation of the victim and perpetrator identities as a SRP. The crucial concern for Koresh is to negotiate for himself the identity of victim and so ascribe perpetrator identity to the FBI. If Koresh achieves this, he attributes predicates to the FBI that are not normatively associated with law enforcement agencies and, by treating these predicates as transposable to the morally selforganized group 'the government', he manages to 'do' subversion by turning the world upside down and reversing the normatively oriented-to moral order. In short, according to who has incumbency of perpetrator identity, the way the siege at Waco is perceived and the way in which the moral order is constructed is radically altered. If Koresh is the victim, the siege can be viewed in terms of state terrorism against an American citizen going about his rightful business. On the other hand, if Koresh has perpetrator identity, the siege is viewed in terms of legitimate state action to repress criminal activity.

\section{$>$ Sequence one}

4.2 In the opening of the telephone call, Koresh avows for himself the identity of victim and claims for himself the identity of a prophet of God. Furthermore, speaking to the FBI negotiator, Henry, he shifts between references of 'you' singular (i.e., the individual FBI negotiator) as distinct from the tactical units of the $\mathrm{FBI}$, the $\mathrm{FBI}$ as a morally self-organized group, and the government as an integral part of that morally self-organized group which is ascribed perpetrator identity. If the government is ascribed perpetrator identity, Koresh is per se the victim and through the workings of the victim-perpetrator SRP Koresh seeks to 'do' subversion by exploiting the moral discrepancies between what he constructs as category-bound (de jure) features of government and category-generated (de facto) features of government. At the same time, he orients to a revolutionary theocratic moral order which accounts for his actions. 

1. FBI: this is Henry
2. K: ahhi Henry this is Dave
3. FBI: hi Dave
4. K: loo:k (.) the er:: (.) the generals out here right $>$ you have a hard time $<$
5. controlling them right
6. FBI: I don't control them no

4.3 After the summons of the ring tone, the FBI agent, Henry, answers the phone and identifies himself. In line 2, Koresh displays recognition of this and indentifies himself, and in the next turn, Henry greets Koresh. In line 4, Koresh introduces the reason for the call which through topic selection makes relevant institutional identities of the FBI. Significantly, in line 4, Koresh explicitly refers to the FBI agents surrounding Mount Carmel as the generals. Through lexical choice, he ascribes a military, rather than law enforcement, identity to the tactical wing of the FBI. This military identity is also perceptually available through the military hardware (armored vehicles and helicopters) and (as will be seen later) it is also action generated through their military style actions. Having categorized the tactical wing of the FBI as 'military' with expectable predicates of waging war rather than enforcing the law, Koresh differentiates Henry from them by saying 'you have a hard time controlling them'. Henry responds in the first person singular and thus confirms Koresh's categorization of a split within the FBI and the military characterization of the tactical wing (line 6: I don't control them no).

4.4 In lines 7 following, Koresh continues his turn:
7. K:
$>$ okay $<$. hh well look (.4) we have done everything we can (.) to be able to (.) communicate
8. in a ni:ce (.7) passionate way (1) we've em (.5) youknow told you what our work with God is
9. (.3) and euh (.) we've been kind (.) we've not been your every day kind of cult (.) we've not
10. been your everyday kind of terrorist (.) which I'm sure you usually have to deal with
11. FBI: uhu

4.5 In line 7, Koresh begins to do category work that, through the use of an inclusive 'we', ascribes himself and his followers the identity 'victims'. First (line 7: we have done everything), he uses an extreme case formulation (Pomerantz 1986) to demonstrate his reasonableness and he ascribes to himself and the Branch Davidians the psychological state of being kind and communicating in a nice and passionate way. Kind people who communicate nicely are not perpetrators of crime. Second, in line 8, Koresh mentions their work with God. If he is working for God, he therefore has, as a predicate associated with one of God's people, a knowledge of what God wants. He thus offers a theological account for his actions which emerges as a leitmotiv in the interaction and which offers a theologically-driven social order rather than a secular one. Third, underscoring his reasonableness, he contrasts his actions with those of an 'everyday kinda cult' and 'everyday kinda of terrorist'. This pre-emptively refutes commonsensical 'what everybody knows' category-bound predicates of unreasonableness, violence, deviance, and so on that could be attributed to him and his followers. This is juxtaposed with self-ascribed psychological states of being kind, nice and passionate which are invoked in the immediately prior talk and which are predicates of victim. In short, Koresh ascribes for himself victim identity and in the continuation of the turn (below) he ascribes the $\mathrm{FBI}$ perpetrator identity and incumbency of the second part of the SRP victim-perpetrator.
11. FBI: uhu
12. K: lot of the things that the FBI or these euh generals are doing is just (.) kinda way beyond the
13. scope of reason (.) and they're not only euh destroying (.) private property (.) euh they're also
14. removing evidences (.3) and this doesn't seem like that erm these=these are moves which
15. should be made by a govemment who > says to a people that we're going to be able
16. to take this up in a court oflaw $<\ldots$ hhh (.) I mean they're not gonna to be able to replace a lot
17. of things here (.) like that sixty eight SS er: el camino that belonged to Paul Fatta?

4.6 In line 11, the FBI agent gives a continuer and in line 12 Koresh continues his turn. In the continuation of his turn, Koresh shifts categorization so as to categorize the FBI and the generals as a collectivity. 'Or' (line 12) in this case is hearable as doing substitution (cf. Jayyusi 1984: 133), so that the FBI and the generals are being treated as synonymous and as part of the same collectivity. Consequently, they are oriented to as having the same predicates and the FBI as a self-organized group is 'doing things way beyond the scope of reason'. In lines 13 and 14, Koresh then gives two examples of this: destroying private property and removing evidences [sic]. The categorizing that Koresh is doing sets up a categorygenerated assessment of performance of the $\mathrm{FBI} /$ generals which stands in contrast to what it commonsensically should be: law enforcement officers do not routinely destroy private property or remove evidence. Through this category work and the setting up of a moral discrepancy between interactionally- 
driven commonsense (de jure) category-bound predicates of the FBI and category-generated (de facto) predicates, the FBI are ascribed the identity 'perpetrator' and Koresh and his followers are incumbent of the identity 'victim'. Having categorized the actions of the FBI as those of a perpetrator, Koresh then projects this onto the government. He does this by explicitly attributing the actions of destroying property and removing evidence, that are physically performed by the FBI tactical wing, to the government (line 14: and this doesn't seem like that erm these=these are moves which should be made by a government). In this way, he orients to the FBI as being situatedly members of the morally self-organizing group 'government'. Consequently, the actions performed by the generals are seen as being done by the government and the predicates that he ascribes to the generals are projected onto the government. Thus, the government becomes an active player in the siege and is ascribed the same perpetrator identity as the FBI agents who are physically carrying out the actions. Koresh's categorization work, therefore, situatedly contrasts category-bound (de jure) predicates of government (respect of property and due legal procedure) with category-generated predicates (non-respect of property and the law) and so he proposes a revolutionary view of the world that challenges the stable moral order (cf. Sacks 1979).

4.7 Further, Koresh invokes the people as part of the SRP government-people (line 14: this doesn't seem like that erm these=these are moves which should be made by a government who $>$ says to a people that we're going to be able to take this up in a court of law). As with any SRP, the categories invoked are bound to each other by a series of rights and obligations, yet in the continuation of his turn Koresh, by treating the government as morally failing in these obligations, sets up a de jure/de facto moral discrepancy. He does this by contrasting the category-generated identity of the government as perpetrators (destroyers of property and removers of evidence) with the normalized/de jure category-bound features of government as representatives of the rule of law. In this way, he attributes routinely non-predicates of government (i.e. destruction of property and non-respect of the law) to the government and so turns the world upside down.

4.8 In the continuation of the turn, Koresh continues to exploit this moral discrepancy and accounts for it by invoking his identity as prophet which he uses to implicitly promote an alternative, theological moral order.

16. K: to take this up in a court of law $<\ldots$. hhh (.) I mean they're not gonna to be able to replace a lot

17. of things here (.) like that sixty eight SS er: el camino that belonged to Paul Fatta?

18. FBI: uhu

19. K: theyll never be able to replace that they don't have any more of those (.) and er the sixty eight camaro and other things they have here out front

21. FBI: uhu

22. K: they can't replace that (.5) they just can't replace it

23. FBI: uhu

24. K: and er they keep they keep doing these kinda things it's just proving to us (.) that they're they're

25. not showing good faith on their part (.4) and I I just suggest they shouldn't do it

26. FBI: I understand what youre saying em and I will impart that euh

27. K: in all courtesies please impart that because because it's come to the point (.). hhh to where

28. er: youknow God in heaven has somewhat to do also (1) and it's just really coming to the

29. point really what do you men really want

4.9 In the continuation of his turn (line 16: they're not gonna to be able to replace a lot of things here), Koresh begins to use the pronoun 'they' which is ambiguous, since it could be a dummy subject, or it could refer to the owners of the cars, or the government that has previously been mentioned. This ambiguity is resolved in line 24: and er they keep they keep doing these kinda things it's just proving to us (.) that they're they're not showing good faith on their part. 'They' is clearly linked to the authors of the complainables (these kinda things, i.e., destroying property) who, as explicated in the previous paragraph, are the collectivity the government'. This is because the physical actions of the FBI and the generals have been transferred to the morally self-organized group the government'. The attribution of these complainables to the government gives Koresh grounds to infer the mental state of 'not showing good faith' which is formulated as a category-generated (de facto) predicate of government which implicitly invokes the moral discrepancy between what the government should be (de jure) and what it actually is (de facto). Koresh proposes a solution to this discrepancy by suggesting that 'they shouldn't do it' (line 25).

4.10 In line 26, Henry acknowledges Koresh's extended turn and states that he will 'impart that'. Koresh continues to claim incumbency of victim identity by ascribing the psychological state of reasonableness to himself because his request to impart the information is done 'in all courtesies'. Furthermore, in the continuation of his turn, Koresh makes explicit his relationship with God which is hearable as offering an account of his actions. The fact that the generals are destroying private property and removing evidence is not only an issue for Koresh, it is also an issue for God: 'God in heaven has somewhat to do also'. Koresh, by invoking God, brings God into the interaction and accounts for his action through his instantiation of SRP prophet-God: the prophet has the predicate of communicating with God and, thus, the moral obligation of following His word. This is contrasted by his description of the FBI as 'you men' which juxtaposes the holy (God) with the profane (man). Moreover, this demonstrative prefaced description is used to 'do' 
disassociation (Stivers 2007). In this case, it is hearable as managing a domain of responsibility in which the obligations that Koresh may be category-bound to respect as citizen are negated. In other words, Koresh both disassociates himself from the people outside, and at the same time strips them of any possible legal status they might have as law enforcement officers by describing them as just 'men'. He thus absolves himself of any responsibilities and obligations that he may have towards them as law enforcement officers.

\section{Sequence two}

4.11 After two minutes, Koresh returns to the same theme of the actions of the generals. By transferring predicates associated with FBI agents to the morally self-organized group the government', he again instantiates the government's incumbency of perpetrator identity. However, this time Koresh specifically invokes his identity as an American citizen and the moral discrepancy caused by the government's breach of their de jure moral responsibilities in the SRP government-citizen. This, again, stresses Koresh's victim identity and proposes an alternative (theocratic) social order.

1. K: well let me tell you this (.) these men (.) who every day we try to show them good faith

2. (.) they've walked out in front of us they've driven their tanks up to us $>$ they've $<$ bashed in

3. the side of a building a little bit one time you said that was er: a mistake it was not in your

4. control it wasn't in the commander's wishes (.) youknow all of this has been shown as=that

5. these guys want to fight (1) now I don't want to fight ( . ) I want=I'm a life too and there are a

6. FBI:

7. K: lot of people in here that are lives=there's children in here

8. FBI: that's right

4.12 In line 1, Koresh again uses the recognitional 'these men' which is, as stated previously, a demonstrative prefaced description which serves to disassociate Koresh from them (the FBI) and to substitute any profession-specific predicates associated with law enforcement officers with universal predicates associated with men. This absolves Koresh from being bound to the obligations inherent in a citizen-law enforcement officer SRP and it also leaves him open to attribute predicates to the FBI officers that are non-profession-specific but which are applicable to 'men'. In this case, he attributes the psychological state of wanting to fight to the FBI. Moreover, whilst he shows 'good faith', which can be a predicate associated with victim identity, these men show action-generated predicates that display perpetrator identity (line 2: they've walked out in front of us, they've driven their tanks up to us, they've bust in the side of the building a little bit one time). First, three-part lists are hearable as standing in for general truths (Potter 1996: 196) and second, in this case, they provide grounds to do a complaint by ascribing general truths about the type of person that 'these men' are. In this way, Koresh continues his categorization work by using the de jure/de facto moral discrepancy, generated by categorizing the FBI as perpetrators, as a truth engine in the doing of subversion.

4.13 Koresh then uses 'you' in the singular form to relate to Henry (line 3: you said) which serves to differentiate Henry from the commanders and which continues the military categorization of the tactical section of the FBI. He then formulates his list of complainables as attributable to the FBI's psychological sate of wanting to fight (line 4: you know all of this has been shown as=that these guys want to fight). This again, explicitly avoids any attribution of legality to the FBI qua law enforcement officers and it reinforces the categorization of the tactical wing of the FBI as military men: generals and commanders who have the category-generated predicate of 'wanting to fight'. Further, as already explicated, by using the recognitional 'these guys', Koresh disavows any possible attribution to the FBI of predicates linked to law enforcement agents. Koresh levels the FBI to the common denominator 'men' who, thus, would have no specific warrant or justification to account for the siege other than 'wanting to fight'. This is then contrasted with Koresh's displayed psychological state of not wanting to fight (line 5: now I don't want to fight). Again this casts him as the victim in the victim-perpetrator SRP. Moreover, to underline his victim status, he invokes the fact that 'there are children in here' which, given the categorization of the FBI as perpetrators wanting to fight, positions the occupants as victims and mobilizes predicates of vulnerability and innocence that are juxtaposed with the FBI's perpetrator identity.

4.14 The FBI agent acknowledges Koresh's turn with an agreement token and then Koresh continues his turn. 
8. FBI: that's right

9. K: we're also Americans and I think=I think that America has a patronage (.) a very clear

patronage of individual citizens who who who who have a breaking point (.) [ the ]

11. FBI:

12. K: govemment's gotten this stronger it can come on to something that we have

13. worked for hard we worked hard when we got on this property (.) a lot of hard hours this place

14. was a dump we fixed it up we built this little house here it's not extravagant (.) you know

15. there's a lot of people here with a high commission and a lot of love and concem not just for

16. our own lives but for everybody's lives andif this is the way our govemment (.) is

17. showing the world what its tactics are to get someone to to to to to do as they wish when in in in re=realistically our=our rights have been infringed upon right and left

4.15 In the continuation of the turn, Koresh specifically invokes his identity as an American and the government's moral failure to live up to their obligations in the SRP government-people. It is noteworthy that Koresh's uses the word patronage (probably here a mistake for the word heritage), which occasions and makes relevant to the interaction the founding ideals of the United States because it suggests continuity and therefore transferability of features across time which may be claimed in respect of being American (cf. Mazeland 2003: 109). This heritage can be traced back to The War of Independence which is generally regarded by Americans as a (just) war to fight the tyranny of monarchy and the excessive demands of the British government. Moreover, these ideas were then codified in The American Constitution and Declaration of Independence which, for example, gave the right to bear arms, to defend private property and so on. Moreover, Koresh then modifies his self-categorization as an American to that of an American citizen (line 10), which, since citizen carries with it political predicates, makes relevant the political dimension of the situation. In short, by invoking American citizenship and individuality, Koresh is avowing incumbency and making relevant to the interaction predicates that are category-bound to the identity of American citizen such as the right to act in self-defense when pushed to breaking point.

4.16 After a micro pause (line 10), the FBI agent seeks to take the floor, but Koresh resumes his turn. In the continuation of his turn, he juxtaposes his self-avowed identity as an American citizen with the secondpart of the American citizen-American government SRP (line 12: 'The government's gotten stronger' and is coming 'on to something that we have worked hard for'). Significantly, it is the FBI who are physically coming on, but Koresh is orienting to the $\mathrm{FBI}$ as part and parcel of the morally self-organized group 'government'. In short, the FBI are an extension of government and so co-incumbents of the same identity. The identity, of which the $\mathrm{FBI}$ and government are co-incumbents, is again that of perpetrator since, as revealed later (line 9), they are acting illegally and infringing Koresh's rights. Koresh then continues his categorization of self and followers as victims who worked hard and built a 'little house'. Lexical choice is an important aspect of Koresh's achievement of victim identity since 'little house' makes relevant predicates of home, peace and so on whereas in fact the building had an armory, underground bunker, and firing ranges. In mobilizing a description of a little house and hard work, Koresh is attributing to himself and followers 'American' characteristics: they are the inheritors of the frontier and the American dream. By contrast, the activities of the government, since they infringe Koresh's rights as an American, are unAmerican. The world is thus turned upside down: the government is un-American and acting illegally, whereas Koresh avows for himself predicates that are normatively category-bound to being American and which are category-generated through his actions of working hard to build for himself a little house in the frontier tradition. These un-American activities of the government are, again, juxtaposed with Koresh's self avowal of mental states that claim incumbency of victim identity (line 15: love and concern not just for our own lives but for everybody's lives). Moreover, the government's actions are specifically those of a bully/perpetrator with the intention of getting someone to do as they wish and which moreover infringe Koresh's rights (lines, 17 and 18). The government is thus ascribed illegality and perpetrator identity and Koresh once again ascribes victim identity to himself and his followers. At the end of Koresh's turn, the $\mathrm{FBI}$ agent attempts to shift topic to the issue of how to resolve the standoff. 
19. FBI: but there's a way to resolve that David [ the ] way to resolve that is for you to come [out

20. $\mathbf{K}$ : [yes ]

21. FBI: andleadyour people out)]

22. $\mathbf{K}$ : your way your way ] you're going to keep destroying (1) our property

23. FBI: this this probably would not have had to happen=

24. K: =it never did have to happen

25. FBI:

26. that's right and and then you know if you had come out on on the day indicated=that

27. $\mathbf{K}$ : you promised that you were gonna come out none of this would have taken place

28. look $<$ you denounce the fact $>$ that I have a God that communicates with me

28. FBI: .hhh

29. K: that's the ( ) the first mistake [we make]

30. FBI: [ no no ] nobody is saying [anything] about

31. $\mathbf{K}$ : [ listen ]

32. FBI: religious beliefs your thoughts [ your ideas ]

33. $\mathbf{K}$ : [but you $\underline{\mathrm{ARE}}$ ]

4.17 In line 19, Henry shifts topic to a way of resolving the standoff and suggests that the way to resolve it is for Koresh to come out. In line 25, he shifts blame to Koresh: you know if you had come out on on the day indicated = that you promised that you were gonna come out none of this would have taken place. Koresh rejects this by accounting for his actions because God communicates with him (line 27: I have a God that communicates with me). Communicating with God is made relevant as an action that is bound to his identity as prophet and as such it accounts for the fact that he does not have to concede to the demands of the FBI. To come out as requested by the FBI would accept incumbency of the identity 'dutiful citizen'. Yet, as seen throughout this analysis, Koresh rejects this possible identity and ascribes to himself the identity prophet which has, as part of its category-bound features, the predicate of speaking to God and thus being morally-bound to follow the directives of God and not man. As such he accounts for his refusal to accede to the FBI demands and so implicitly proposes a theocratic, rather than secular, social order. Koresh, thus, orients to what Jayyusi (1984: $134 \mathrm{ff.}$.) has termed a category dilemma (i.e., the potential practical relevance of two, contextually oppositional, categories - in this case citizen and prophet). Koresh resolves this dilemma by making relevant his category incumbency of the identity 'prophet' and so accounts for his refusal to come out: God's, not Man's, demands are more relevant to his identity. In making this choice, he renders unto God the things that are God's but fails to render unto Caesar the things that are Caesar's and so he does subversion by proposing a theocratic rather than secular moral order.

\section{Observations and conclusions}

5.1 As stated in the introduction, working within a cumulative paradigm of social research whereby finegrained analyses of single cases come together with others to provide a thick description of an area of enquiry, this paper seeks to add to previous work on the mobilization of moral discrepancies in political discourse. Working on the premise that the social order is talked into being through, inter alia, the way in which members categorize each other, this paper has sought to explicate how Koresh is able to do subversion by making interactionally relevant a moral discrepancy between category-bound (de jure) predicates associated with government and category-generated (de facto) predicates. The moral discrepancy device works, on this occasion, through; invoking the relevance of the victim-perpetrator SRP, ascribing perpetrator identity to law enforcement officers, and transferring these same predicates to the government.

5.2 In the case of Koresh, he positions himself as the victim. This is the first part of a SRP which makes perpetrator identity, as the other identity in the pair, immediately relevant. The perpetrator in this transcript varies on a turn by turn basis between the FBI as a whole and the tactical wing of the FBI (the generals). What is significant is that Koresh treats the law enforcement officers, who are physically present at the scene, as members of the morally self-organized group 'the government'. Consequently, the actions and category-generated features of those physically present are treated as the actions and category-generated features of the government. In this way, a moral discrepancy is made interactionally relevant: routinely category-bound (de jure) predicates of government such as respect of property, the rule of law, and the concern for rights of American citizens are juxtaposed with category-generated (de facto) predicates such as non-respect of law, wanting to fight, and willful destruction of property that are associated with perpetrator identity. The moral discrepancy allows Koresh to categorize the government as a morally bankrupt collectivity that is acting in an un-American and illegal fashion and this accounts for his actions of not complying with requests to leave the building and end the standoff. Further, through categorizing himself as incumbent of the identity 'prophet', he is able to propose a theocratic moral order as a replacement for the current, morally bankrupt, political order. He thus does subversion.

5.3 For subversion to become revolution, the category-generated features that Koresh proposes would have to become, as Sacks (1979) states, the categories through which members routinely and normatively perceive reality. Yet, Sacks (1979) offers no explication as to how a revolutionary category such as 
'hotrodder' could establish itself as a stable reference and so achieve revolution. Korešh died in the conflagration that engulfed Mount Carmel on the day following the recording and the categorizing that he puts forward has not become the stable reference by which people see the world. But, nevertheless, Koresh's category work was revolutionary to the extent that it was a fundamental attack against a government which is stable only to the extent that people do not routinely orient to themselves as victims and to the government as perpetrators of this victimization. Further research could be carried out to attempt to consider the question of what makes one form of categorization stable, normative, and hegemonic and another revolutionary in the way that Sacks (1979) accounts for the categories 'teenage driver' and 'hotrodder'. Similarly, whilst Eglin and Hester (2003: 55) note that 'category work is at the heart of terrorism', further research could also be carried out to see the extent to which victim-perpetrator identities and the moral discrepancy that is made relevant through the juxtaposition of situatedly invoked category-bound (de jure) and category-generated (de facto) predicates is present in, or a stable feature of, other subversive discourse such as, for example, those of anarchists, militia groups, or terrorists.

Appendix one: transcription symbols used
$\begin{array}{ll}(2.5) & \text { approximate length of pause in seconds } \\ \text { [but] } & \text { overlapping utterances } \\ : & \text { sound stretching } \\ >\text { problem < } & \text { spoken more quickly that surrounding words } \\ <\text { problem> }>\quad \text { spoken more slowly than surrounding words } \\ \text { (X) } & \text { syllable in untranscribable talk } \\ \text {.hh } & \text { inbreath } \\ \text { way } & \text { stressed word } \\ \text { ARE } & \text { spoken more loudly than surrounding words } \\ = & \text { word latched to a following word } \\ \text { ? } & \text { spoken with rising intonation } \\ \text { (.) } & \text { micro-pause }\end{array}$

\section{Notes}

${ }^{1}$ Available at: <http://www.usdoj.gov/05publications/waco/wacotocpg.htm\#toc>

${ }^{2}$ Available at : <http://www.apfn.net/audio/L001/060324084324-Koresh-FBI-4-18-93.MP3>

${ }^{3}$ Available at: <http://www.serendipity.li/waco/ tapes.html>

\section{References}

COULTER, J. (1996) 'Human practices and the observability of the 'macrosocial', Zeitschrift für Soziologie, Vol. 35, No. 5, pp. 337-345.

EGLIN, P. and Hester, S. (1999) 'You're all a Bunch of Feminists: Catgeorization and the Politics of Terror in the Montreal Massacre', Human Studies, Vol. 22, 253-272.

EGLIN, P. and Hester, S. (2003) The Montreal Massacre. A story of membership categorization analysis. Waterloo, Ont. : Wilfrid Laurier University Press.

HESTER, S. (1994) 'Les catégories en contexte'. In B. Fradin, L. Quéré, and J. Widmer (eds.) L'enquête sur les catégories. Paris: École des Hautes Études en Sciences Sociales.

GARFINKEL, H. (1967) Studies in ethnomethodology. Englewood Cliffs, N.J. : Prentice-Hall.

HESTER, S. and Eglin, P. (1997a) 'Membership categorization analysis: an introduction'. In S. Hester and P. Eglin (eds.) Culture in action: studies in membership categorization analysis. Washington, D.C.: University Press of America.

HESTER, S. and Eglin, P. (1997b) 'Conclusion: Membership categorization analysis and sociology'. In S. Hester and P. Eglin (eds.) Culture in action: studies in membership categorization analysis. Washington, 
HOUSLEY, W. (2002) The Moral Discrepancy Device and Fudging the Issue in a Political Radio News Interview', Sociology, Vol. 34, No. 3, pp. 5-21.

HOUSLEY, W. and Fitzgerald, R. (2001) 'Categorisation, Narrative and Devolution in Wales' Sociological Research Online, Vol. 6, No. 2, <http://www.socresonline.org.uk/6/2/housley.html>

HOUSLEY, W. and Fitzgerald, R. (2002) The reconsidered model of membership categorization analysis', Qualitative Research, Vol. 2, No. 1, pp. 59-83.

HOUSLEY, W. and Fitzgerald, R. (2003) 'Moral Discrepancy and Political Discourse: Accountability and the Allocation of Blame in a Political News Interview', Sociological Research Online, Vol. 8, No. 2, <http://www.socresonline.org.uk/8/2/housley.html>

HOUSLEY, W. and Fitzgerald, R. (2009) 'Membership categorization, culture and norms in action', Discourse and Society, Vol. 20, No. 3, pp. 345-362.

JAYYUSI, L. (1984) Categorization and the moral order. Boston, etc. Routledge \& Kegan Paul.

LEUDAR, I., Marsland, V. and Nekvapil, J. (2004) 'On membership categorization: 'us', 'them' and 'doing violence' in political discourse', Discourse \& Society, Vol. 15, No. 2-3, pp. 243-266.

MAZELAND, H. (2003) 'A politician's sociology. US Vice President Gore's categorization of the participants in the Warsaw Uprising'. In T. Ensink and C. Sauer (eds) The art of commemoration. Fifty years after the Warsaw Uprising. Amsterdam / Philadelphia: John Benjamins.

POMERANTZ, A. (1986) 'Extreme case formulations: A way of legitimizing claims', Human studies, Vol. 9, pp. 219-230.

POTTER, J. (1996) Representing Reality: Discourse, Rhetoric and Social Construction. London: Sage.

SACKS, H. (1972a) 'On the analyzability of stories by children'. In J.J. Gumperz, and D. Hymes (eds.) Directions in sociolinguistics: the ethnography of communication. New York: Rinehart \& Winston.

SACKS, H. (1972b) 'An initial investigation of the usability of conversational data for doing sociology'. In D. Sudnow (ed.) Studies in social interaction. New York: Free Press.

SACKS, H. (1979) 'Hotrodder: a revolutionary category'. In G. Psathas (ed.) Everyday language: studies in ethnomethodology. New York: Irvington.

SACKS, H. (1992) Lectures on conversation. 2 vols. Edited by Gail Jefferson with introductions by Emanuel A. Schegloff. Oxford: Basil Blackwell.

STIVERS, T. (2007) 'Alternative recognitionals in initial references to persons'. In T. Stivers and N.J. Enfield (eds.) Person Reference in Interaction: Linguistic, Cultural, and Social Perspectives. Cambridge University Press.

WILSON, T.P. (1991) 'Social structure and the sequential organisation of interaction'. In D. Boden and D.H. Zimmerman (eds), Talk and Social Structure. Studies in Ethnomethodology and Conversation Analysis. Oxford: Polity Press. 